Jurnal Ilmu-Ilmu Peternakan 26 (2): 30 - 41

ISSN : 0852-3681

E-ISSN : 2443-0765

CFakultas Peternakan UB, http://jiip.ub.ac.id/

\title{
Pengaruh penambahan kultur azotobacter pada feses kambing terhadap kualitas media dan produktivitas cacing tanah (Lumbricus rubellus)
}

\author{
Nur Cholis ${ }^{1}$, Endang Setyowati ${ }^{2}$ dan Ita Wahju Nursita ${ }^{3}$ \\ ${ }^{1}$ Laboratorium Produksi Aneka Ternak, Fakultas Peternakan, Universitas Brawijaya \\ ${ }^{2}$ Laboratorium Produksi Ternak Perah, Fakultas Peternakan, Universitas Brawijaya \\ ${ }^{3}$ Laboratorium Fisiologi Ternak, Fakultas Peternakan, Universitas Brawijaya
}

\begin{abstract}
The purposes of this research were to determine the effect of addition of Azotobacter bacterial culture into media of goat faeces on medium quality and earthworm productivity; and also to examine the best dose of Azotobacter bacterial cultures addition. The research material was 800 g earthworm aged 3 months old. The research method was experimental with Completely Randomized Design using 4 treatments and 4 replications. The results show that addition of Azotobacter bacterial culture had a significant effect $(\mathrm{P}<0.01)$ on the medium quality and earthworm productivity (coccoon production, the number of juvenils per coccoon, coccoon hatching percentage, the numbers and weight of earthworm). The bacterial culture addition of $350 \mathrm{cc} / 100 \mathrm{~kg}$ goat faeces was found the best. We suggest to follow the study with observation about the effect of the length of fermentation to the medium quality and earthworm productivity.
\end{abstract}

Keywords: Azotobacter, goat faeces, earthworm

\section{PENDAHULUAN}

Populasi kambing di Indonesia mengalami peningkatan selama 5 tahun terakhir dari 1.305.078 ekor pada tahun 2011 menjadi 1.381.331 ekor pada tahun 2015. Pertumbuhan populasi kambing di Indonesia pada tahun 20142015 mencapai 3,46\% (Badan Pusat Statistik, 2015). Meningkatnya populasi kambing di Indonesia juga diiringi dengan meningkatnya limbah feses dan urin kambing. Kambing yang berbobot 25-30 kg menghasilkan feses rata-rata 300-500 g/ekor/hari dan urin sebanyak 0,5-1 liter/hari. Potensi produksi limbah kambing tersebut memerlukan penanganan yang baik agar tidak mencemari lingkungan dan juga untuk estetika. Pengolahan limbah feses dan urin dapat memberikan tambahan pendapatan bagi peternak dengan mengubahnya menjadi pupuk kandang untuk tanaman. Menurut Sudiarto (2008), konversi limbah menjadi pupuk organik akan sangat berperan dalam pemulihan daya dukung lingkungan terutama di bidang pertanian.

Cacing tanah (Lumbricus

rubellus) merupakan hewan invertebrata yang bermanfaat antara lain: menyuburkan lahan pertanian, sebagai bahan industri obat dan kosmetik. Cacing tanah yang mengandung protein tinggi dan asam amino lengkap menjadi salah satu alternatif yang potensial untuk dijadikan imbuhan pakan. Tepung cacing tanah memiliki kadar protein kasar $65,63 \%$ dan asam amino prolin 
sekitar 15\% dari total 62 asam amino (Hayati, 2011). Pemberian tepung cacing tanah (TCT) sebagai pakan ternak ayam terbukti mempercepat pertumbuhan berat hidup, meningkatkan pembentukan jaringan otot, dan meningkatkan efisiensi pakan.

Pertumbuhan cacing tanah sangat ditentukan oleh media yang diberikan. Salah satu cara meningkatkan pertumbuhan cacing tanah dengan memberi media yang difermentasi. Penggunaan feses kambing dipilih karena mengandung 75,35\% bahan organik, protein kasar 17,84\%, lemak 0,92\%, dan serat kasar 2,85\% (Mashur, 2001). Unsur hara feses kambing mengandung nitrogen $1,50 \%$, fosfor 0,30\%, kalium 1,80\%, dan air 60\%. Kandungan nutrisi kotoran kambing meningkat setelah menjadi kompos. Hasil uji kandungan nutrisi kompos berbasis kotoran kambing diperoleh karbon organik 30,7\% dari bahan kering, nitrogen $(\mathrm{N})$ 1,73\%, fosfor $2,57 \%$, kalium $1,56 \%$ dan sulfur $0,34 \%$.

Tingginya karbon organik dalam kompos kotoran kambing merupakan pertanda baik karena karbon bersama dengan nitrogen merupakan komponen yang dapat digunakan oleh mikroorganisme untuk metabolisme (Noviani, 2009). Pemberian kultur bakteri Azotobacter diharapkan meningkatkan kandungan protein feses kambing yang dibutuhkan cacing tanah. Kandungan protein yang dibutuhkan media yaitu 60-72\%. Oleh karena itu, pemberian kultur bakteri Azotobacter diharapkan mampu meningkatkan kandungan protein pada feses kambing yang digunakan sebagai media cacing tanah. Kultur bakteri Azotobacter itu sendiri memerlukan sumber energi seperti karbon dan fosfat untuk dapat memfiksasi nitrogen (Wedhastari, 2002). Tersedianya nutrisi bagi kultur bakteri Azotobacter dapat membantu mengoptimalkan peran kultur bakteri tersebut dalam menjaga dan meningkatkan kesuburan tanah serta dapat meningkatkan protein. Kultur bakteri Azotobacter merupakan salah satu aktivator yang dapat membantu mempercepat proses fermentasi karena dibantu oleh mikroorganisme yang dapat menguraikan bahan organik yang bermanfaat untuk meningkatkan protein media cacing tanah. Tujuan penelitian ini adalah untuk mengetahui bagaimana pengaruh penambahan kultur bakteri Azotobacter pada feses kambing terhadap kualitas media dan produktivitas cacing tanah. Hasil penelitian ini diharapkan dapat digunakan sebagai informasi ilmiah tentang pemanfaatan feses kambing sebagai media cacing tanah dengan penambahan kultur bakteri Azotobacter.

\section{MATERI DAN METODE}

Penelitian ini dilaksanakan pada 2 Januari - 2 Februari 2016 di kediaman Bapak Imam Suwasono Dusun Bedali, Desa Campursari, Kecamatan Sambit, Kabupaten Ponorogo.

\section{Materi penelitian}

Peralatan yang digunakan dalam penelitan ini meliputi timbangan analitik, termometer, indikator $\mathrm{pH}$, polybag dan sarung tangan. Bahan yang digunakan sebagai media adalah feses kambing, kultur mikroba Azotobacter, air, molases, air gula dan cacing tanah. Spesies cacing tanah yang digunakan dalam penelitian ini adalah Lumbricus rubellus seberat $800 \mathrm{~g}$ dengan umur produktif \pm 3 bulan. Penentuan umur pada cacing tanah dapat dilihat melalui ada atau tidaknya klitellum dimana cacing tanah dewasa atau produktif umumnya mempunyai klitellum pada usia 2,5-3 bulan.

Pembuatan larutan dekomposer dilakukan dengan menyiapkan peralatan 
dan bahan seperti kultur bakteri Azotobacter, air, air gula dan molasses. Kemudian semua bahan dimasukkan kedalam wadah lalu dihomogenkan.

Pembuatan media cacing tanah dibedakan atas dua yaitu tanpa fermentasi $\left(\mathrm{P}_{0}\right)$ dan terfermentasi $\left(\mathrm{P}_{1}\right.$, $\mathrm{P}_{2}, \mathrm{P}_{3}$ ). Pada pembuatan media cacing tanah tanpa fermentasi, feses kambing dibersihkan dari benda asing. Feses kambing kemudian dihaluskan menggunakan penumbuk. Selanjutnya dimasukkan dalam polybag sebanyak satu $\mathrm{kg} /$ media tanpa diberi perlakuan apapun kecuali pemberian air. Pada pembuatan media cacing tanah terfermentasi, setelah feses kambing dibersihkan dari benda asing dan ditumbuk kemudian ditambahkan larutan dekomposer pada feses dan dihomogenkan. Feses kemudian dimasukkan kedalam polybag dan difermentasi secara anaerob selama 2 hari. Setelah difermentasi polybag diisi dengan media sebanyak satu kg untuk setiap perlakuan.

Sebelum digunakan untuk penanaman dan pemeliharaan cacing tanah, media yang telah difermentasi diangin-anginkan selama satu hari untuk mengurangi panas dan gas, kemudian dilakukan uji biologis dengan memasukkan beberapa ekor cacing ke media. Media sudah dapat digunakan sebagai tempat hidup cacing tanah apabila dalam waktu 24 jam, cacing tersebut tidak keluar atau mati. Pemberian pakan dilakukan seminggu dua kali. Pakan yang diberikan berupa feses kambing yang ditambahkan dengan kultur bakteri Azotobacter sesuai perlakuan masing-masing media 150cc $\left(\mathrm{P}_{1}\right)$, 250cc $\left(\mathrm{P}_{2}\right)$ dan 350cc $\left(\mathrm{P}_{3}\right)$. Sedangkan penyiraman dilakukan setiap tiga hari sekali untuk menjaga kelembaban media. Perhitungan kebutuhan media didasarkan pada bobot dewasa cacing tanah (a gram) dan lama pemeliharaan (b hari) (Brata, 2008). Selanjutnya dinyatakan bahwa kebutuhan cacing tanah terhadap pakan dihitung sebanyak dua kali bobot badan.

\section{Metode penelitian}

Metode penelitian yang digunakan adalah metode percobaan rancangan acak lengkap sebanyak 4 perlakuan dan setiap perlakuan diulang sebanyak 4 kali $(4 \times 4)$, sehingga terdapat 16 unit percobaan dalam penelitian. Keempat perlakuan tersebut adalah $\mathrm{P}_{0}$ : Feses kambing tanpa penambahan kultur bakteri Azotobacter (kontrol)

$\mathrm{P}_{1}$ : Kultur bakteri Azotobacter 150cc/100kg feses kambing

$\mathrm{P}_{2}$ : Kultur bakteri Azotobacter 250cc/100kg feses kambing

$\mathrm{P}_{3}$ : Kultur bakteri Azotobakter 350cc/100kg feses kambing).

Variabel yang diamati adalah kualitas media dan produktivitas cacing tanah. Variabel produktivitas cacing tanah yang diamati meliputi produksi kokon cacing tanah, jumlah anak per kokon (ekor/kokon/media), persentase daya tetas (\%/media), jumlah cacing tanah dan pertambahan bobot cacing tanah. Kualitas media diketahui dari hasil analisis proksimat yang dilakukan di Laboratorium Kimia FMIPA UB. Produksi kokon cacing tanah dihitung pada akhir pemeliharaan dengan lama pemeliharaan selama 4 minggu. Perhitungan dilakukan dengan cara menghitung satu persatu kokon yang dihasilkan cacing tanah pada setiap unit percobaan. Penghitungan jumlah anak setiap kokon diperoleh dari jumlah anak cacing tanah yang dihasilkan dibagi dengan pengurangan antara jumlah kokon yang diinkubasi dengan jumlah kokon yang tidak menetas. Penghitungan persentase daya tetas diperoleh dari pengurangan jumlah kokon yang diinkubasi dengan kokon yang tidak menetas dibagi dengan 
jumlah kokon yang diinkubasi dikali seratus persen. Jumlah cacing tanah diketahui dari perhitungan selisih antara jumlah cacing tanah awal dan akhir pemeliharaan. Pertambahan bobot cacing tanah diketahui dengan menghitung selisih antara bobot awal dan bobot akhir pemeliharaan.

Data yang diperoleh dianalisis menggunakan analisis ragam metode Rancangan Acak Lengkap (RAL) (Astuti, 2007) dilanjutkan dengan uji jarak berganda (UJBD) untuk mengetahui dosis terbaik. Model analisisnya sebagai berikut:

$Y_{i j}=\mu+\tau_{i}+\varepsilon_{i j}$

$Y_{i j}$ : Nilai pengamatan pada perlakuan

ke-i ulangan ke-j

$\mu$ : Nilai tengah umum

$\tau_{\mathrm{i}}$ : Pengaruh perlakuan ke-i

$\varepsilon_{\mathrm{ij}}$ : Kesalahan (galat) percobaan pada perlakuan ke-i ulangan ke-j

\section{HASIL DAN PEMBAHASAN}

Tekstur feses kambing sangat khas karena berbentuk butiran yang agak susah dipecah secara fisik sehingga berpengaruh terhadap proses dekomposisi. Kandungan hara feses kambing sebelum dikomposkan berdasarkan bahan segar adalah $\mathrm{C}$ 46,51\%, N 1,41\%, C/N 32,98, P 0,54\% dan K 0,75\%. Fermentasi feses kambing dilakukan selain untuk meningkatkan kandungan nutrisi pada media juga mampu meningkatkan kualitas media. Media mempunyai peran penting untuk pertumbuhan dan perkembangan cacing tanah. Feses kambing difermentasi dengan kultur bakteri Azotobacter pada perlakuan (P1, P2, P3) selama dua hari (48 jam).

Menurut SNI-19-7030-2004, persyaratan kematangan fermentasi adalah suhu sesuai dengan air tanah tidak lebih dari $30^{\circ} \mathrm{C}$, berwarna kehitaman tekstur seperti tanah dan tidak berbau. Suhu media cacing tanah sebelum fermentasi pada masingmasing perlakuan yaitu $25^{\circ} \mathrm{C}$. Suhu media selama proses fermentasi berkisar $38-39^{\circ} \mathrm{C}$. Pada hari ke-2 suhu fermentasi berhenti pada suhu $28-29^{\circ} \mathrm{C}$ seperti yang tertera pada Gambar 1.

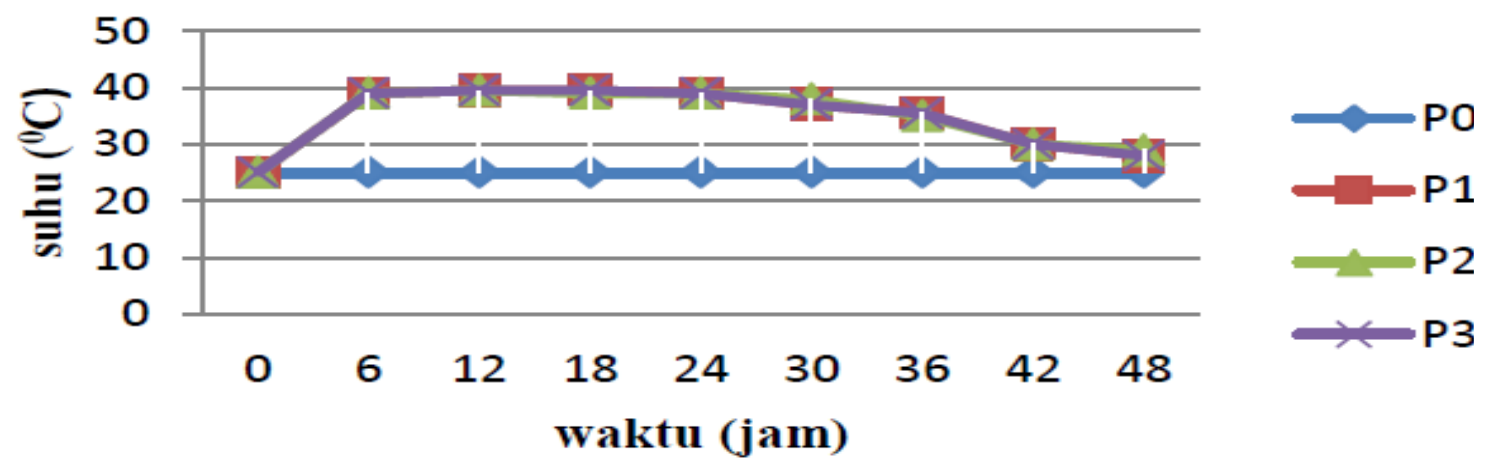

Gambar 1. Grafik proses fermentasi

Suhu proses fermentasi secara umum mengalami fluktuatif. Pada awal menunjukkan suhu yang tinggi pada perlakuan (P1, P2, P3) kemudian suhu semakin menurun di semua perlakuan. Suhu hari terakhir pada jam ke-48 proses fermentasi berkisar $28-29^{\circ} \mathrm{C}$.
Suhu media cacing tanah selama pemeliharaan (30 hari) pada perlakuan P0 berkisar $25,5^{\circ} \mathrm{C}$. Suhu untuk perlakuan (P1, P2, P3) berkisar pada $27,5-29^{\circ} \mathrm{C}$. Suhu rata-rata perlakuan ini sudah sesuai untuk keberlangsungan hidup cacing tanah. Suhu ruangan juga 
berpengaruh terhadap suhu media. Media yang panas dapat didinginkan dengan menyiram media menggunakan air secukupnya.

$\mathrm{pH}$ media cacing tanah sebelum fermentasi pada perlakuan (P1) yaitu 8, (P2) sebesar 7 dan (P3) sebesar 8. pH sesudah fermentasi secara berurutan adalah 7, 6, dan 6. Xueling (2006) menyatakan bahwa $\mathrm{pH}$ optimum bakteri yang terlibat dalam fermentasi berkisar 6.0-7,5. pH fermentasi matang yaitu
8,2-8,3, sedangkan SNI-19-7030-2004 menyebutkan $\mathrm{pH}$ minimal 6,8 dan maksimal 7,49. $\mathrm{pH}$ selama pemeliharaan mempunyai rerata sebesar 8,2-8,3. Fermentasi dapat berjalan efektif pada rentang $\mathrm{pH}$ yang optimum.

Fermentasi feses kambing dengan penambahan kultur bakteri Azotobacter dapat meningkatkan kandungan protein kasar dan menurunkan serat kasar seperti yang tertera pada Tabel 1 .

Tabel 1. Kandungan nutrisi feses kambing sebagai media cacing tanah dalam penelitian

\begin{tabular}{cccccc}
\hline Perlakuan & PK (\%) & SK(\%) & LK (\%) & Abu (\%) & Kadar air(\%) \\
\hline P0 & 9,49 & 71,63 & 0,75 & 0,87 & 16,48 \\
P1 & 9,62 & 54,31 & 0,66 & 1,01 & 47,53 \\
P2 & 9,98 & 51,58 & 0,37 & 1,16 & 50,41 \\
P3 & 10,54 & 47,68 & 0,35 & 2,31 & 59,07 \\
\hline
\end{tabular}

Sumber: Laboratorium Kimia, Fakultas MIPA, Universitas Brawijaya, Malang, Jawa Timur (2016)

Tabel 1 menunjukkan bahwa secara umum terjadi peningkatan terhadap kandungan protein kasar, abu, dan kadar air tetapi pada serat kasar dan lemak kasar mengalami penurunan. Hal tersebut disebabkan enzim yang dihasilkan oleh kultur bakteri Azotobacter mampu memecah selulosa selama proses fermentasi menjadi glukosa. Enzim selulosa merupakan enzim komplek yang bekerja secara bertahap atau bersamaan untuk memecah selulosa menjadi glukosa. Selanjutnya glukosa yang dihasilkan dari subtrat akan digunakan sebagai sumber karbon dan energi. Media cacing tanah yang mengandung protein tinggi dan serat kasar yang rendah diperoleh dari perlakuan P3.

Protein meningkat setelah difermentasi dengan kultur bakteri Azotobacter karena rangkaian enzim dan perubahan kimia oleh mikroorganisme meliputi perubahan molekul kompleks atau senyawa organik seperti protein, karbohidrat dan lemak menjadi molekul sederhana dan mudah dicerna. Perombakan protein diubah menjadi polipeptida, selanjutnya menjadi peptida sederhana dan dirombak menjadi asam-asam amino. Asam-asam amino ini yang akan dimanfaatkan oleh bakteri untuk memperbanyak diri. Jumlah koloni bakteri yang merupakan sumber protein tunggal menjadi meningkat selama proses fermentasi. Kandungan protein kasar pada media cacing tanah yang rendah ditunjukkan oleh perlakuan P0 atau tanpa ada perlakuan fermentasi dengan kultur bakteri Azotobacter. Schlegel dan Schmidt (1994) menyatakan bahwa menurunnya kecepatan pertumbuhan bakteri disebabkan oleh keterbatasan substrat, kepadatan populasi mikroorganisme yang tinggi, tekanan persial yang rendah, kekurangan faktor pertumbuhan dan juga timbunan produk metabolisme yang mengandung toksik. Anggorodi (1994) menyatakan bahwa bakteri 
mampu menghasilkan enzim protease yang akan merombak protein.

Kandungan serat kasar terendah ditemukan pada perlakuan P3. Faktorfaktor yang menyebabkan penurunan serat kasar pada media cacing tanah tersebut antara lain perlakuan penumbukan. Hal tersebut sesuai dengan pendapat Xueling (2006) bahwa penumbukan merupakan perlakuan yang mampu menghancurkan sebagian ikatan jaringan serat kasar dengan memperluas permukaan dan membuka struktur dinding sel, sehingga memungkinkan mikrobia probiotik untuk menembus lapisan pelindung dinding sel dan memperbanyak titik penetrasi enzim agar mudah dicerna. Anggorodi (1994) menambahkan bahwa perlakuan penumbukan atau penggilingan bahan berserat tinggi dapat mengurangi ukuran partikel, merusak struktur kristal selulosa dan memutus ikatan kimia dan rantai panjang molekul penyusunnya.

Kandungan lemak kasar pada media cacing tanah masing-masing perlakuan menunjukkan penurunan terendah pada perlakuan P3 karena bakteri Azotobacter pada proses fermentasi substrat merombak lemak untuk digunakan sebagai energi pertumbuhan bakteri. Kandungan abu pada media cacing tanah terbesar ditunjukkan pada perlakuan P3 karena peningkatan kadar abu disebabkan adanya penambahan kultur bakteri Azotobacter dalam proses fermentasi. Kadar abu yang dibutuhkan media cacing tanah sebesar 8-10\%.

Tabel 1 menunjukkan bahwa pada perlakuan tanpa fermentasi diperoleh kandungan kadar air yang paling rendah dibandingkan dengan perlakuan lainnya. Peningkatan kadar air pada media terjadi karena adanya peningkatan aktivitas mikroba yang akan menghasilkan uap air sehingga mampu meningkatkan kadar air media. Bila kadar air turun di bawah $40 \%$, maka aktivitas bakteri akan melambat. Aktivitas akan berhenti seluruhnya bila kadar air di bawah 15\%. Menurut Hoitink (2008), kadar air optimal untuk fermentasi adalah 45\%-55\%.

\section{Pengaruh penambahan kultur bakteri Azotobacter terhadap jumlah anak per kokon pada cacing tanah}

Jumlah anak yang dihasilkan pada setiap kokon merupakan salah satu faktor yang mendukung keberhasilan reproduksi pada usaha cacing tanah karena jumlah anak per kokon erat kaitannya dengan kemampuan cacing tanah dalam bereproduksi. Kokon diinkubasi selama satu minggu pada tempat yang terpisah. Hasil analisa rataan jumlah anak per kokon selama penelitian disajikan pada Tabel 2.

Tabel 2. Rataan jumlah anak per kokon pada setiap media

\begin{tabular}{cc}
\hline Perlakuan & Rataan anak per kokon (ekor) \\
\hline P0 & $2.59 \pm 0.37^{\mathrm{a}}$ \\
P1 & $3.21 \pm 0.16^{\mathrm{b}}$ \\
P2 & $3.55 \pm 0.12^{\mathrm{b}}$ \\
P3 & $4.70 \pm 0.54^{\mathrm{c}}$ \\
\hline Rataan & $3.51 \pm 0.29$ \\
\hline
\end{tabular}

Keterangan : Superskrip yang berbeda pada kolom yang sama menunjukkan perbedaan yang sangat nyata $(\mathrm{P}<0.01)$ 
Jumlah anak per kokon pada Tabel 2 menunjukkan bahwa media yang ditambahkan dengan kultur bakteri Azotobacter menunjukkan hasil yang beragam dikarenakan tidak semua kokon yang diinkubasi menetas dan menghasilkan anak. Analisis ragam menunjukkan bahwa ada pengaruh sangat nyata $(\mathrm{P}<0.01)$ dari jenis media terhadap jumlah anak per kokon yang dihasilkan. Hasil Uji Jarak Berganda Duncan (UJBD) menunjukkan bahwa jumlah anak per kokon yang dihasilkan pada perlakuan $\mathrm{P} 1, \mathrm{P} 2$, dan $\mathrm{P} 3$ berbeda sangat nyata $(\mathrm{P}<0.01)$ terhadap $\mathrm{P} 0$. Secara keseluruhan rata-rata produksi anak per kokon cacing tanah adalah 3.51. Menurut Minnich (1977), setiap kokon rata-rata dapat menghasilkan 4 anak cacing, sedangkan Subowo (2008) menyatakan bahwa dalam perkembangannya butuh 14-21 hari bagi kokon agar menetas dan menghasilkan juvenile. Setiap kokon akan menghasilkan 1-8 ekor anak atau juvenile. Kokon cacing tanah berdiameter sekitar 1,2 cm.
Rendahnya jumlah anak per kokon yang dihasilkan disebabkan karena media pemeliharaan yang kurang diperhatikan selama berlangsungnya penelitian, seperti terkena cahaya, adanya predator seperti semut ataupun kelabang yang memakan anak cacing. Selain itu, waktu penghitungan dilakukan terlalu dini (empat minggu setelah inkubasi berakhir) atau kurang dari yang dianjurkan (6 minggu) sehingga kondisi anak cacing tanah masih melekat satu sama lain dan menyulitkan dalam perhitungan.

\section{Pengaruh penambahan kultur bakteri Azotobacter terhadap persentase daya tetas kokon cacing tanah}

Persentase daya tetas merupakan kemampuan kokon dalam menentaskan dan menghasilkan anak. Semakin tinggi persentase daya tetas kokon maka produktivitas cacing tanah semakin baik sehingga mampu meningkatkan produksi anak cacing tanah. Rataan persentase daya tetas kokon cacing tanah dapat dilihat pada Tabel 3.

Tabel 3. Rataan daya tetas kokon cacing tanah

\begin{tabular}{cc}
\hline Perlakuan & Rataan $(\%)$ \\
\hline $\mathrm{P}_{0}$ & $38.71 \pm 2.92^{\mathrm{a}}$ \\
$\mathrm{P}_{1}$ & $44.50 \pm 1.28^{\mathrm{b}}$ \\
$\mathrm{P}_{2}$ & $47.03 \pm 0.87^{\mathrm{b}}$ \\
$\mathrm{P}_{3}$ & $52.88 \pm 4.86^{\mathrm{c}}$ \\
\hline Rataan & $45.78 \pm 2.48$
\end{tabular}

Keterangan : Superskrip berbeda pada kolom yang sama menunjukkan perbedaan sangat nyata $(\mathrm{P}<0.01)$

Pada media yang ditambahkan kultur bakteri Azotobacter diketahui bahwa $\mathrm{P}_{3}$ menghasilkan persentase daya tetas tertinggi (52.88\%) dalam waktu 30 hari. Analisis ragam menunjukkan bahwa ada pengaruh sangat nyata $(\mathrm{P}<0.01)$ perlakuan terhadap daya tetas kokon cacing tanah. Rata-rata daya tetas kokon cacing tanah pada keseluruhan media adalah $45.78 \%$ dalam waktu 30 hari dan persentase daya tetas ini dapat dikatakan baik. Hasil penelitian yang dilakukan oleh Anderson, et al. (2013) menunjukkan bahwa persentase daya tetas kokon cacing tanah Lumbricus rubellus $80 \%$ dengan asumsi kokon 
ditetaskan selama 56 hari. Rendahnya daya tetas kokon cacing tanah pada penelitian ini disebabkan oleh kondisi lingkungan media selama pemeliharaan kurang diperhatikan sebagaimana disebutkan sebelumnya sehingga memungkinkan kokon tidak mampu menetas pada hari yang sama. Apabila suhu hangat, maka telur cacing bisa menetas dalam waktu 3 minggu, namun apabila suhu dingin maka telur cacing baru akan menetas di usia 3 bulan. Selain itu, jarak antara penetasan kokon cacing tanah dengan pemanenan anak cacing yang terlalu cepat (30 hari) sehingga kemungkinan masih ada kokon yang belum menetas. Oleh karena itu, perhitungan daya tetas sebaiknya dilakukan dengan rentang waktu lebih panjang setelah proses penetasan untuk memaksimalkan menetasnya kokon secara keseluruhan.

\section{Pengaruh penambahan kultur bakteri Azotobacter terhadap jumlah cacing tanah}

Jumlah cacing tanah mengalami peningkatan pada semua perlakuan dari masing-masing jumlah awal yang berbeda-beda. Pertambahan dan jumlah akhir tertinggi ditunjukkan oleh perlakuan $\mathrm{P}_{3}$ seperti yang tertera pada Tabel 4.

Tabel 4. Pertambahan populasi cacing tanah masing-masing perlakuan

\begin{tabular}{|c|c|c|c|c|}
\hline Perlakuan & $\begin{array}{c}\text { Jumlah awal total } \\
\text { (ekor) }\end{array}$ & $\begin{array}{l}\text { Jumlah akhir total } \\
\text { (ekor) }\end{array}$ & \multicolumn{2}{|c|}{ Pertambahan jumlah } \\
\hline P0 & 428 & 803 & 375 & 87,61 \\
\hline P1 & 407 & 960 & 553 & 135,8 \\
\hline $\mathrm{P} 2$ & 369 & 1195 & 827 & 224,1 \\
\hline P3 & 335 & 1457 & 1125 & 335,8 \\
\hline
\end{tabular}

Keterangan: Data primer yang sudah diolah

Peningkatan jumlah akhir pada semua perlakuan dikarenakan peningkatan kandungan nutrisi media terutama protein kasar sehingga mampu menyuplai nutrisi bagi cacing tanah untuk berkembang. Diagram jumlah akhir cacing tanah masing-masing perlakuan disajikan pada Gambar 2.

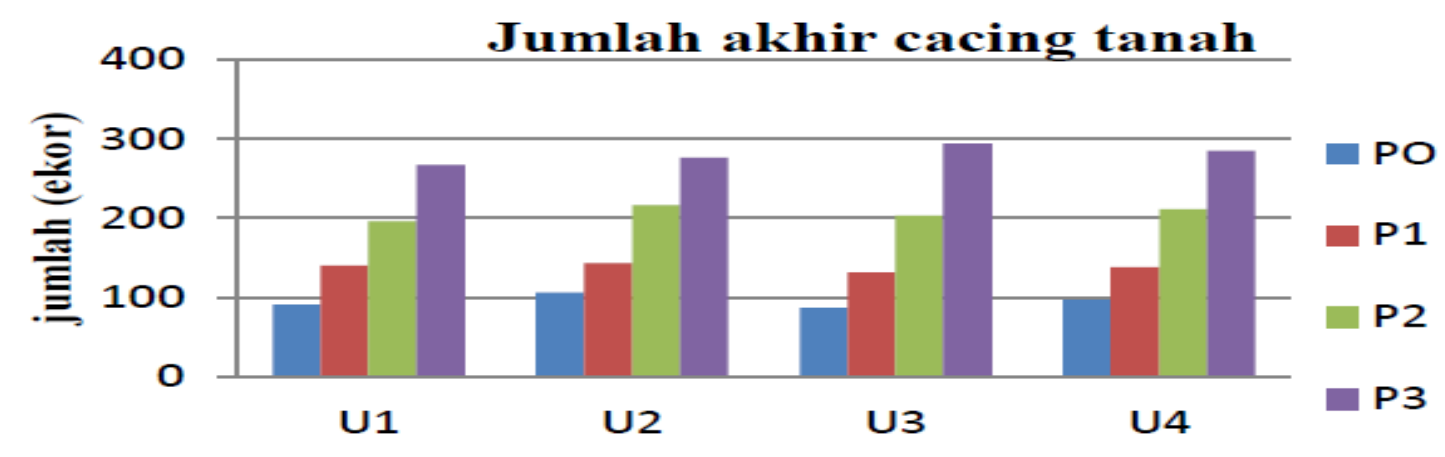

Ulangan

Gambar 2. Diagram jumlah akhir cacing tanah setiap perlakuan

Diagram jumlah akhir cacing tanah di atas secara umum menerangkan terjadinya peningkatan pertambahan jumlah cacing tanah dengan meningkatnya pemberian kultur mikroba. Pertambahan jumlah cacing 
tanah tertinggi ditunjukkan oleh perlakuan $\mathrm{P}_{3}$ dengan dosis $350 \mathrm{cc} / 100 \mathrm{~kg}$ pakan. Pertumbuhan cacing tanah dipengaruhi oleh media cacing tanah.
Rataan jumlah akhir cacing tanah mengalami peningkatan pada semua perlakuan seperti yang terlihat pada Tabel 5.

Tabel 5. Rataan jumlah awal dan akhir cacing tanah

\begin{tabular}{ccc}
\hline Perlakuan & Rataan jumlah awal (ekor) & Rataan jumlah akhir \pm SD (ekor) \\
\hline P0 & 107 & $200,7 \pm 17,2^{\mathrm{a}}$ \\
P1 & 101,75 & $240 \pm 15,7^{\mathrm{b}}$ \\
P2 & 92,25 & $298,7 \pm 19,3^{\mathrm{c}}$ \\
P3 & 83,75 & $364,25 \pm 19,3^{\mathrm{d}}$ \\
\hline
\end{tabular}

Keterangan : Superkrip berbeda menunjukkan perbedaan sangat nyata $(\mathrm{P}<0,01)$

Rataan tertinggi ditunjukkan oleh perlakuan $\mathrm{P}_{3}$ dan rataan terendah ditunjukkan oleh $\mathrm{P}_{0}$. Pakan cacing tanah berupa feses kambing yang difermentasi dengan kultur bakteri Azotobacter mampu memenuhi kebutuhan cacing tanah untuk bertelur dan menambah bobot badan cacing tanah karena cukupnya asupan yang terkandung dalam media. Perbandingan jumlah awal dan akhir setiap perlakuan disajikan pada Gambar 3.

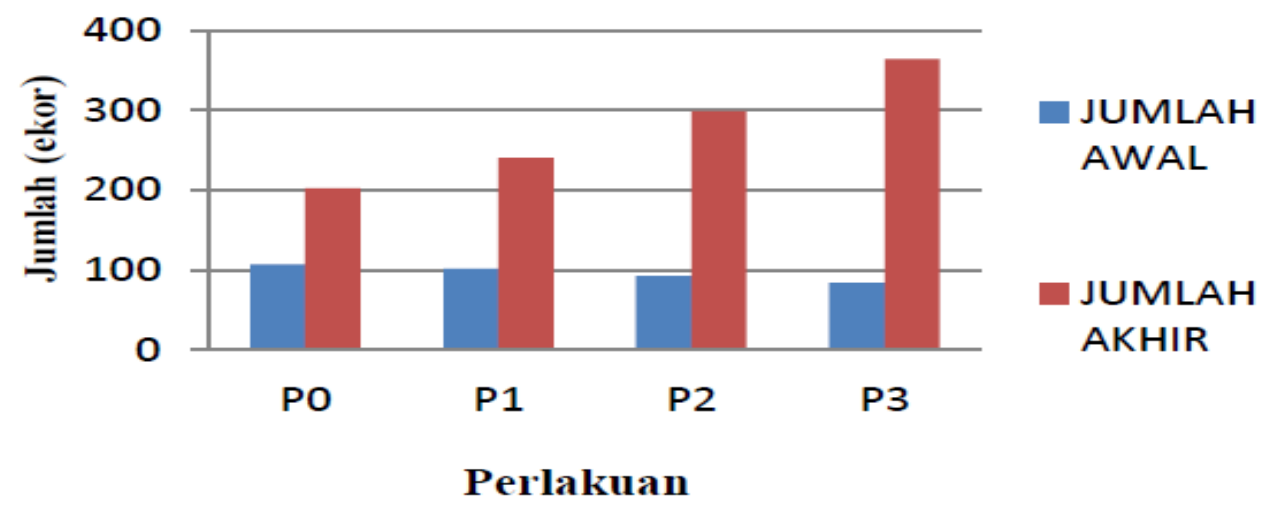

Gambar 3. Perbandingan jumlah awal dan akhir cacing tanah

Diagram diatas menunjukkan bahwa secara umum terjadi peningkatan jumlah cacing tanah. Pertambahan jumlah awal dan akhir tertinggi ditunjukkan oleh perlakuan $\mathrm{P}_{3}$. Aslamyah (2012) menyatakan dari segi produktivitasnya, cacing Lumbricus rubellus lebih unggul dari pada jenis lainnya seperti jenis Megascolocidae. Lama pemeliharan cacing tanah pada penelitian selama satu bulan. Siklus hidup cacing tanah dimulai dari perkawinan sepasang cacing tanah yang mampu menghasilkan kokon yang berisi telur. Selama 7-10 hari setelah perkawinan, cacing dewasa akan menghasilkan satu kokon yang akan menetas dalam waktu 14-21 hari. Setiap kokon akan menghasilkan 2-20 ekor atau rata-rata 4 ekor cacing tanah. Menurut Brata (2008), 100 ekor cacing tanah diperkirakan dapat menghasilkan 100.000 ekor cacing tanah dalam waktu 1 tahun.

\section{Pengaruh penambahan kultur bakteri Azotobacter terhadap pertambahan bobot cacing tanah}

Feses kambing yang difermentasi dengan kultur bakteri 
Azotobacter berpengaruh $(\mathrm{P}<0,01)$

tanah seperti yang ditunjukkan pada terhadap pertambahan bobot cacing Tabel 6.

Tabel 6. Pertambahan bobot cacing tanah selama 30 hari

\begin{tabular}{ccccc}
\hline Perlakuan & Bobot awal total & Bobot akhir total & \multicolumn{2}{c}{ Pertambahan bobot } \\
\cline { 4 - 5 } & $(\mathrm{g})$ & $(\mathrm{g})$ & $(\mathrm{g})$ & $(\%)$ \\
\hline $\mathrm{P}_{0}$ & 200 & 273 & 73 & 36,5 \\
$\mathrm{P}_{1}$ & 200 & 307 & 107 & 53,5 \\
$\mathrm{P}_{2}$ & 200 & 326 & 126 & 63 \\
$\mathrm{P}_{3}$ & 200 & 391 & 191 & 95,5 \\
\hline
\end{tabular}

Keterangan : Data primer yang sudah diolah

Pertambahan bobot cacing tanah secara keseluruhan mengalami peningkatan, dimana pada perlakuan P3 menunjukkan bobot tertinggi. Bobot cacing tanah yang meningkat di setiap perlakuan disebabkan oleh peningkatan kandungan nutrisi terutama protein kasar dan menurunnya kadar serat kasar sehingga tersedia asupan nutrisi bagi cacing tanah. Diagram peningkatan bobot akhir cacing tanah secara keseluruhan ditampilkan pada Gambar 4.

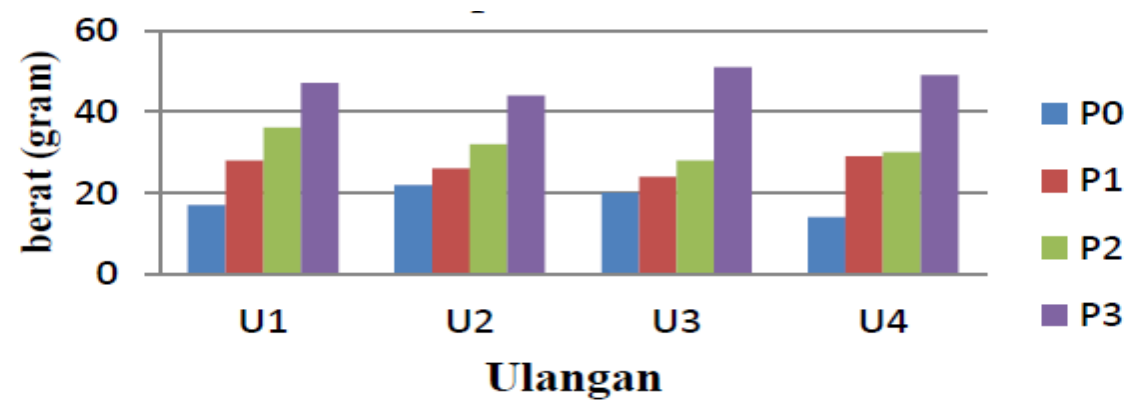

Gambar 4. Diagram bobot akhir cacing tanah pada masing-masing perlakuan

Pada Gambar 4 terlihat bahwa bobot cacing tanah secara keseluruhan mengalami kenaikan dari masingmasing perlakuan dan ulangan. Hal tersebut dikarenakan tersuplainya nutrisi untuk media cacing tanah. Keunggulan jenis Lumbricus diantaranya mudah dalam pemeliharaan dan perawatan, tidak berbau, dan memiliki produktivitas yang tinggi. Dosis $350 \mathrm{cc} / 100 \mathrm{~kg}$ pakan pada fermentasi feses kambing dengan kultur bakteri Azotobacter merupakan dosis terbaik yang ditunjukkan dengan ratarata bobot akhir tertinggi seperti yang tertera pada Tabel 7.

Tabel 7. Rataan bobot akhir cacing tanah selama 30 hari

\begin{tabular}{ccc}
\hline Perlakuan & Bobot awal $(\mathrm{g})$ & Bobot akhir $(\mathrm{g}) \pm$ SD \\
\hline $\mathrm{P}_{0}$ & 50 & $68,2 \pm 3,5^{\mathrm{a}}$ \\
$\mathrm{P}_{1}$ & 50 & $76,7 \pm 2,1^{\mathrm{bc}}$ \\
$\mathrm{P}_{2}$ & 50 & $81,5 \pm 3,4^{\mathrm{c}}$ \\
$\mathrm{P}_{3}$ & 50 & $97,7 \pm 2,9^{\mathrm{d}}$ \\
\hline
\end{tabular}

Keterangan : Superskrip yang berbeda menunjukkan perbedaan sangat nyata $(\mathrm{P}<0,01)$ 
Rataan bobot akhir cacing tanah secara keseluruhan mengalami kenaikan di setiap perlakuan. Hal tersebut dikarenakan jenis Lumbricus rubellus mampu berkembang secara cepat dan mudah beradaptasi dengan lingkungan. Ketersediaan pakan yang cukup selama pemeliharaan dibuktikan dengan berat media pemeliharaan yang berkisar 2,82,9 kg dari pemeliharaan awal $1 \mathrm{~kg}$. Pertambahan berat akhir media dikarenakan media sudah bercampur dengan kotoran cacing tanah selama pemeliharaan. Pertambahan media masing-masing perlakuan berkisar 1,2$1,9 \mathrm{~kg}$. Berat media akhir pemeliharaan yang bertambah dijadikan nutrisi tambahan cacing tanah untuk memperbanyak diri.

\section{KESIMPULAN DAN SARAN}

Berdasarkan hasil penelitian dapat disimpulkan bahwa penambahan kultur bakteri Azotobacter pada feses kambing meningkatkan kualitas media dan produkstivitas cacing tanah. Media dengan penambahan kultur bakteri Azotobacter $350 \mathrm{cc} / 100 \mathrm{~kg}$ merupakan perlakuan terbaik. Namun, perlu dilakukan penelitian lebih lanjut tentang lama fermentasi terhadap kualitas media yang dihasilkan dan produktivitas cacing tanah.

\section{DAFTAR PUSTAKA}

Anderson, C. J. P. Kille. A. J. Lawlor and D. J. Spurgeon. 2013. LifeHistory effects of arsenic toxicity in clades of the earthworm Lumbricus rubellus. Enviromental Pollution 172 200207.

Anggorodi. 1994. Ilmu makanan ternak umum. Gramedia Pustaka Utama Jakarta.

Aslamyah. 2012. Uji organoleptik, fisik, dan kimiawi pakan buatan untuk ikan Bandeng yang didistribusi dengan tepung cacing tanah (Lumbricus sp). Jurnal Akuakultur Indonesia. 11 (2). Hal 124-131.

Astuti, M. 2007. Pengantar ilmu statistik untuk peternakan dan kesehatan hewan. Binasti. Bogor.

Badan Pusat Statistik. 2015. Data populasi kambing tahun 2010 2015 Indonesia. Direktorat Jenderal Peternakan dan Kesehatan Hewan.

Brata, B. 2008. Kualitas eksmecat dari beberapa spesies cacing tanah pada tingkat penyiraman dan pengapuran yang berbeda. Jurnal Sain Peternakan Indonesia Vol. 3, No 1.

Hayati. 2011. Peningkatan kadar N, P, $\mathrm{K}$ tersedia serta kenaikan $\mathrm{pH}$ akibat keberadaan cacing tanah (P.heretima sp) pada tanah utilisol. Jurnal Pengembang Wilayah Lahan Kering. Hal 14: 1-10.

Hoitink. 2008. Control the office composting process. Ohio State Universitiy. Engeneering, New York Lewish Publisher. Hal 546.

Mashur. 2001. Vermikompos (kompos cacing tanah) pupuk organik berkualitas dan ramah lingkungan. Instalasi Penelitian dan Pengkajian Teknologi Pertanian (IPPTP). Mataram.

Minnich, J. 1977. Earthworm book rodale. Press. Inc., Emmaus, PA.

Noviani. 2009. Reduksi gas dinitrogen monoksida melalui biofiltrasi dengan menggunakan material kompos termodifikasi. Jurnal kimia. Vol. 1.

Schlegel, H. dan K. Schmidt. 1994. Mikrobiologi umum. Edisi keenam. Penerjemah: Tedjo, B. Yogyakarta: GMU Press. 
Subowo, G. 2008. Prospek cacing tanah untuk pengembangan teknologi resapan biologi di lahan kering. Balai Pengkajian Teknologi Pertanian Yogyakarta. Yogyakarta.

Standart Nasional Indonesia (SNI) Pengomposan No.19-70302004.

Sudiarto. 2008. Pengelolaan limbah peternakan terpadu dan agribisnis yang berwawasan lingkungan. Seminar Nasional
Teknologi Peternakan dan

Veteriner. Universitas

Padjajaran. Bandung. Hal : 52

Wedhastri, S. 2002. Isolasi dan seleksi

Azotobacter spp penghasil faktor tumbuh dan penambat nitrogen dari tanah masam. Jurnal Ilmu Tanah dan Lingkungan. Vol. 3: 45-51.

Xueling. 2006. Nitrogen transformation in food waste composting. Enviromental Eingeneering : University of Ragina. 